\title{
Современное состояние картофелеводства и овощеводства в Иркутской области
}

\section{Н.И. Большешапова, И.Н. Абрамова, Е.В. Бояркин, С.П. Бурлов}

Дана оценка современного уровня развития отрасли картофелеводства и овощеводства в Иркутской области. Рассмотрены посевные площади, урожайность, валовый сбор картофеля и овощей в регионе. Даны рекомендации по совершенствованию отрасли картофелеводства и овощеводства в Иркутской области.

Ключевые слова: картофелеводство, овощеводство, урожайность, валовой сбор, посевные площади.

K артофель в Иркутской области - один из основных продуктов питания населения [1]. Картофелеводство и овощеводство - важнейшие отрасли производства в Иркутской области.

Возделыванием картофеля и овощей в Иркутской области занимаются три категории производителей: с.х. организации, КФХ и хозяйства населения. Основные лидеры в регионе среди с.- Х. организаций: СХ ПАО «Белореченское», ЗАО «Иркутские семена», АО «Железнодорожник», ОАО «Искра», АО «Тепличное» г. Ангарск и др.

Удельный вес продукции растениеводства по Сибирскому Федеральному округу за 2017 год показал, что по с.- х. организациям Иркутская область занимала девятое место среди других регионов, по хозяйствам населения и КФХ - пятое место соответственно.

Площади под картофелем и овощами в Иркутской области в 2018 году составляли 26,3 тыс. га, 4,2 тыс. га соответственно (табл. 1). Урожайность картофеля осталась на

низком уровне - 14-15 т/га, валовый сбор составлял 393,3 тыс. т, в свою очередь урожайность овощей увеличилась на 4,6\% (табл. 2).

В с.- Х. организациях собрали картофеля на 0,1 тыс. т меньше, чем в 2017 году. Фермеры в сравнении с 2000 годом увеличили посадки картофеля и овощей соответственно в 1,5 и 2 раза. Однако в общем производстве этих сельхозкультур их доля остается невысокой (8-14\%). Сбор картофеля и овощей в регионе традиционно обеспечивают главным образом хозяйства населения. В 2018 году в хозяйствах населения собрали 317,4 тыс. Т картофеля и 75,9 тыс. т овощей. Однако постепенно их вклад в общем объеме производства снижается. Если в 2000 году личные подсобные хозяйства обеспечивали $96 \%$ областного урожая картофеля и 93\% овощей, то в 2018 году соответственно $81 \%$ и $69 \%[2,3,4,5,6]$.

Среди 85 субъектов РФ Иркутская область в 2018 году занимала 28 место. Потребление овощей в Иркутской
Таблица 1. Площади под картофелем и овощами в с. - х. организациях, КФХ и хозяйствах населения Иркутской области за 2013-2018 годы, тыс. га

\begin{tabular}{|c|c|c|c|c|c|c|c|}
\hline \multirow{2}{*}{ Категории хозяйств } & \multicolumn{6}{|c|}{ Год } & \multirow{2}{*}{$\begin{array}{c}2018 \text { год } \\
\text { в\% } \\
\text { к } 2013 \text { году }\end{array}$} \\
\hline & 2013 & 2014 & 2015 & 2016 & 2017 & 2018 & \\
\hline \multicolumn{8}{|c|}{ картофель } \\
\hline С.- х. организации & 3,6 & 3,3 & 3,3 & 2,9 & 2,6 & 2,1 & 58,3 \\
\hline КФX & 1,3 & 1,5 & 1,7 & 1,9 & 1,8 & 2,2 & 169,2 \\
\hline Хозяйства населения & 36,5 & 36,6 & 35,8 & 35,7 & 34,2 & 22,0 & 60,3 \\
\hline \multicolumn{8}{|c|}{ овощи } \\
\hline С.-х. организации & 0,9 & 0,7 & 0,7 & 0,6 & 0,7 & 0,5 & 55,6 \\
\hline КФX & 0,04 & 0,04 & 0,03 & 0,04 & 0,04 & 0,06 & 150,0 \\
\hline Хозяйства населения & 0,5 & 0,5 & 0,5 & 0,5 & 0,5 & 0,3 & 60,0 \\
\hline
\end{tabular}

области в 2017 году составляло 86 кг на душу населения в год, что ниже рекомендуемой нормы на 54 кг (в 1,6 раза). Потребление картофеля 126 кг, что выше рекомендуемой величины на 36 кг (в 1,4 раза). Динамика потребления картофеля за последние годы характеризуется стабильным уровнем (126-127 кг/год) [7].

По сравнению с 2013 годом площадь под картофелем уменьшилась на 15,1 тыс. га, а овощей - на 0,9 тыс. га. В среднем по региону основная часть выращивания картофеля и овощей приходится на хозяйства населения. Хозяйства населения уменьшают посадки по причине трудоемкости возделывания и снижения потребности в картофеле как корма для скота из-за сокращения поголовья на личных подворьях.

В 2018 году площадь посадок картофеля в с.- х. организациях составляла 2,1 тыс. га, в КФХ - 2,2 тыс. га и в хозяйствах населения - 22,0 тыс. га. По региону с.- х. организации и КФХ в общей сложности выращивали картофель на площади 4,2 тыс. га (16,3\% общей площади посадок хозяйств всех категорий). Остальные $83,7 \%$ возделывали в хозяйствах населения, с низкой долей применения механизированного оборудования и преимущественной долей тяжелого ручного труда.

Незначительное количество площадей в Иркутской области приходится на овощные культуры. Возделыванием овощных культур также занимаются три категории производителей, как и при производстве картофеля. В структуре производства овощей в регионе наибольшая доля приходится на с.- х. организации $(58,1 \%)$, второе место занимают хозяйства населения (34,9\%), третье-КФХ (6,8\%).

С 2013 по 2018 годы в динамике по Иркутской области наблюдалось повышение урожайности картофеля по всем категориям хозяйств за исключением 2015 года. В этот период по региону 
Таблица 2. Валовой сбор картофеля и овощей в хозяйствах всех категорий в Иркутской области за 2013-2018 годы, тыс. т

\begin{tabular}{|l|c|c|c|c|c|c|c|c|}
\hline & \multicolumn{7}{|c|}{ Год } \\
\hline Категории хозяйств & 2013 & 2014 & 2015 & 2016 & 2017 & 2018 & $\begin{array}{c}2018 \text { в\% } \\
\text { К } 2103\end{array}$ \\
\hline & \multicolumn{7}{|c|}{ картофель } \\
\hline С.- х. организации & 46,2 & 53,8 & 29,9 & 56,9 & 40,9 & 40,8 & 88,3 \\
\hline КФХ & 18,0 & 24,1 & 21,5 & 30,6 & 30,9 & 35,1 & 195 \\
\hline Хозяйства населения & 509,1 & 522,4 & 501,7 & 519,6 & 495,7 & 317,4 & 62,3 \\
\hline & & \multicolumn{7}{|c|}{ овощи } \\
\hline С.- х. организации & 18,7 & 18,4 & 14,8 & 21,4 & 16,2 & 18,3 & 97,9 \\
\hline КФХ & 7,5 & 7,5 & 5,6 & 7,6 & 10,3 & 15,4 & 205,3 \\
\hline Хозяйства населения & 121,6 & 127,0 & 128,4 & 125,8 & 116,3 & 75,9 & 62,4 \\
\hline
\end{tabular}

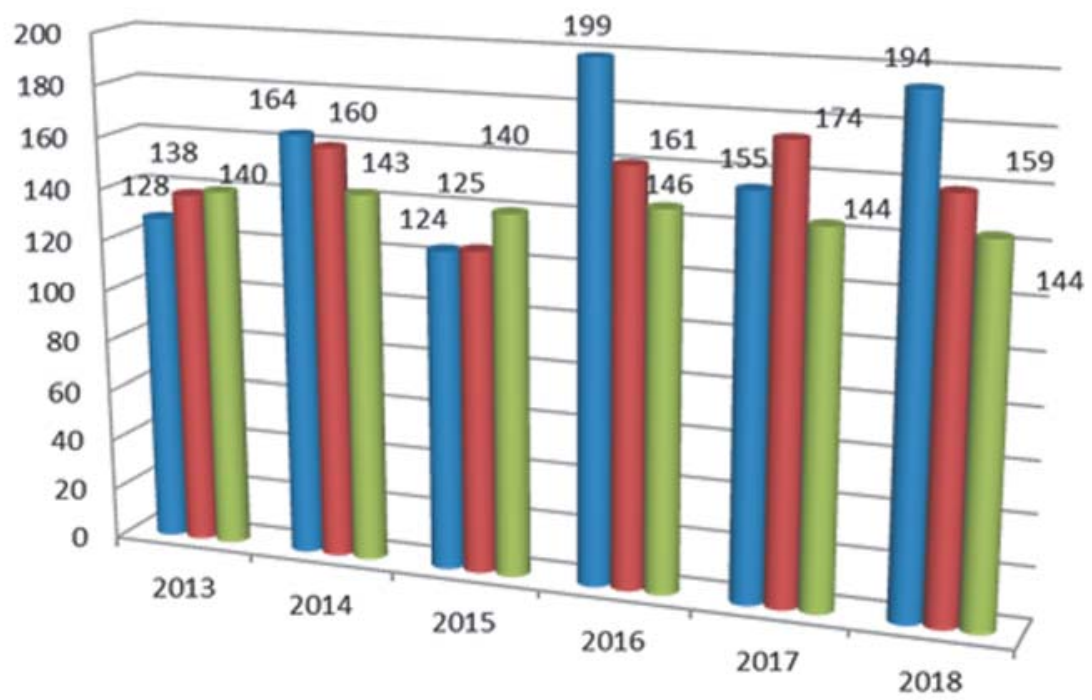

=Сельскохозяйственные организашии $=К(Ф) \mathrm{X} \equiv$ Хозяйства населения

Pис. 1. Урожайность картофеля по всем категориям хозяйств в Иркутской области, ц/га

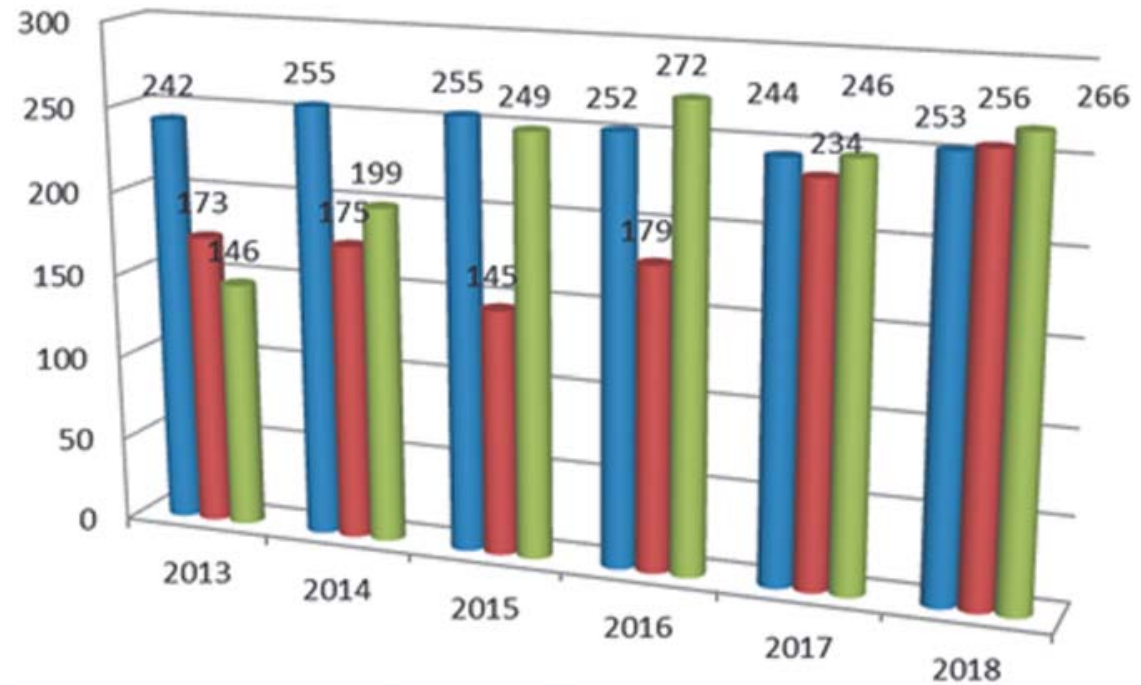

= Хозяйства населения $=\mathrm{K}(Ф) \mathrm{X}$ = Сельскохозяйственные организаци

Рис. 2. Урожайность овощей по всем категориям хозяйств в Иркутской области, ц/га была отмечена засуха, что сказалось на урожайности картофеля (рис. 1).

По урожайности овощей (рис. 2) наблюдалось увеличение. Наибольшие результаты показали с.х. организации и КФХ, за счет применения механизированного комплекса агротехнических мероприятий $[6,7,8]$.

Валовый сбор картофеля в 2018 году по всем категориям хозяйств составил 393,3 тыс. т, т.е. по сравнению с 2013 годом уменьшился на 180 тыс. т (табл. 2). По производству овощной продукции этот показатель снизился на 38,2 тыс. т.

По производству картофеля и овощей в хозяйствах населения прослеживается тенденция снижения валового сбора картофеля на 191,7 тыс. т, овощей - на 45,7 тыс. т в 2018 году по сравнению с 2013 годом. В с. - х. организациях и КФХ наблюдалось повышение валового сбора.

Таким образом, для совершенствования отрасли картофелеводства и овощеводства в Иркутской области необходимо:

- увеличение площадей возделывания картофеля и овощей в с.х. организациях, КФХ и хозяйствах населения;

- внедрение современных технологических агроприемов, в том числе применения оросительных систем при возделывании картофеля и овощей;

- строительство и иодернизация современных овоще- и картофелехранилищ;

- внедрение в с.- х. производство региона высокоурожайных, адаптированных к местным условиям выращивания сортов овощных культур и картофеля;

- создание в регионе семеноводческих хозяйств, занимающихся размножением оригинальных семян для применения в производстве картофеля и овощей семян и посадочного материала высших репродукций;

- увеличенные государственной поддержки при возделывании овощной продукции и картофеля для повышения экономической эффективности производства.

\section{Библиографический список}

1.Большешапова Н.И. Оценка сортов и гибридов картофеля на экологическую пластичность и стабильность урожайности, качества клубней в лесостепи Иркутской области: автореф. дис. ... канд. с.- х. наук. Тюмень, 2019. 16 с.

2.Статистический ежегодник Сельское хозяйство, охота и лесоводство Иркутской области в 2016 году: статистический сборник. Иркутск, 2017. 205 с.

3.Статистический ежегодник Сельское хозяйство, охота и лесоводство Иркутской области в 2017 году: статистический сборник. Иркутск, 2018. 199 с. 
4.Статистический ежегодник Сельское хозяйство, охота и лесоводство Иркутской области в 2018 году: статистический сборник. Иркутск, 2019. 185 с.

5.Сельское хозяйство Иркутской области в цифрах (2017). Иркутск, 2017. 29 с

6.Сельское хозяйство Иркутской области в цифрах (2018). Иркутск, 2018. 45 с.

7.0 результатах анализа питания населения Иркутской области [Электронный ресурc] URL: http://38. rospotrebnadzor.ru/news/-/asset_publisher/0Xcw/content/ id $/ 650787 /$ pop up; jsessionid=8734898A916151501E BF58E3B89C69F7.worker38?_101_INSTANCE_0Xcw_ viewMode=print. Дата обращения: 09.09.19.

8.Посевные площади и валовые сборы сельскохозяйственных культур в 2017 году: статистический бюллетень. Иркутск, 2018. 201 с.

\section{Об авторах}

Большешапова Надежда Ивановна, аспирант, кафедра земледелия и растениеводства агрономического факультета. E-mail: nade1982@mail.ru

Абрамова Ирина Николаевна, канд. биол. наук, доцент, кафедра земледелия и растениеводства агрономического факультета.

E-mail: irinanikabramova@mail.ru

\section{Бояркин Евгений Викторович,}

канд. биол. наук, доцент, кафедра земледелия и растениеводства агрономического факультета.

E-mail: boyarkinevgenii@mail.ru

Бурлов Сергей Петрович, канд. с. х. наук, доцент, кафедра земледелия и растениеводства агрономического факультета

Иркутский государственный аграрный университет имени А.А. Ежевского

Current state of potato and vegetable growing in Irkutsk region

N.I. Bolsheshapova, post-graduate student, Department of Agriculture and Plant Science, Faculty of Agronomy.

E-mail: nade1982@mail.ru

I.N. Abramova, $P h D$, assoc. prof., Department of Agriculture and Plant

Science, Faculty of Agronomy.

E-mail: irinanikabramova@mail.ru

Y.V. Boyarkin, $P h D$, assoc. prof.,

Department of Agriculture and Plant

Science, Faculty of Agronomy.

E-mail: boyarkinevgenii@mail.ru

S.P. Burlov, PhD, assoc. prof., Department of Agriculture and Plant Science, Faculty of Agronomy

Irkutsk State Agrarian University named after Ezhevskiy

Summary. The assessment of the current level of development of potato and vegetable in dustry in the Irkutsk region. Sown areas, yield, gross harvest of potatoes and vegetables in the region are considered. Recommendations for improvement of potato and vegetable growing industry in Irkutsk region are given.

Keywords: potato growing, vegetable growing, yield, gross harvest, acreage. 